\title{
Mass Customization for Social Housing in Evolving Neighborhoods in Brazil
}

\author{
Luisa Felix Dalla Vecchia ${ }^{1, * \mathbb{C}}$ and Branko Kolarevic ${ }^{2}$ \\ 1 School of Architecture Planning and Landscape, University of Calgary, Calgary, AB T2N 1N4, Canada \\ 2 Hillier College of Architecture and Design, New Jersey Institute of Technology, University Heights, \\ Newark, NJ 07102, USA; branko.r.kolarevic@njit.edu \\ * Correspondence: luisa.felixdallavecc@ucalgary.ca
}

Received: 22 September 2020; Accepted: 28 October 2020; Published: 30 October 2020

\begin{abstract}
Mass customization is being adopted in many housing contexts worldwide to provide families with dwellings that suit their individual needs at costs similar to mass-produced items. However, in many social housing contexts, there are barriers that can hinder the adoption of mass customization, despite the benefits it could bring to residents. This is the case in the Brazilian social housing context considering house units for families of the lowest income range. This paper explores the possibilities and limitations of applying mass customization in this context to improve the living conditions in these neighborhoods as they evolve over time. This study analyzes the ecology of the system of provision of social housing for the lowest income range, pre-occupancy, and post-occupancy in the neighborhood's development over time. This study argues that it would be more feasible and bring more and longer-lasting benefits to the stakeholders involved if mass customization were applied post-occupancy.
\end{abstract}

Keywords: mass customization; social housing; post-occupancy

\section{Introduction}

This study investigates how mass customization could be applied in Brazil to social housing developments to promote better environments for the families and the neighborhood over time. Mass customization can be defined as "a system that uses information technology, flexible processes, and organizational structures to deliver a wide range of products and services that meet specific needs of individual customers (often defined by a series of options), at a cost near that of mass-produced items" [1]. In housing, individual customization is traditionally seen as hiring an architect to creatively design a unique home, ideal for the family. Mass housing, on the other hand, is when large numbers of identical homes are built and then sold for much less than the uniquely designed homes. Mass customization promises the best of both approaches: uniquely designed products that better fit the user's needs with mass production efficiency and costs [2,3]. It is being adopted in many housing contexts worldwide to provide families with dwellings that suit their individual needs at costs similar to the mass-produced ones.

Mass customization of housing has been linked to environmental and social sustainability [4]. By providing dwellings that better suit the individual needs of the family, there is less need for renovations and the waste it creates. Furthermore, construction for mass customization often adopts practices, such as prefabrication, which also reduce waste and water and energy consumption. The custom home also increases the users' sense of identity and ownership towards it. However, most cases of mass customization in housing do not consider the spatial needs of the user; the user is limited to choosing their preferences in elements such as surface materials, colors, and finishes [5]. Several examples from industry and research that have addressed mass customization in housing have 
also considered needs in terms of space, including the kind of space, the relationships between them, and how much space the users need or want $[4,6-8]$. This approach that includes the spatial aspects shows the greatest potential to avoid unnecessary demolitions and renovations and even to allow families to stay in the same home for longer. This is especially relevant when moving is difficult or not an option, such as for lower-income families for whom mass housing is often the norm.

Several studies have shown how the concept of mass customization and its tools could be used to satisfy each family's needs in mass housing [8-11]. However, in many social housing contexts, there are added barriers that can hinder the adoption of mass customization, despite the benefits it could bring for families. This is the case in the Brazilian context with house units for the lowest income range of the population. Some construction companies in Brazil have started mass customizing their housing products for higher-income housing developments, allowing the customers to choose from standard interior and very few exterior elements. This approach makes a significant difference in terms of the customer expressing their individuality and territoriality and increasing their sense of ownership. However, in most cases, the different spatial needs are not addressed since the definition of how much space and how it is organized stays the same. Furthermore, despite studies suggesting that there would be benefits in adopting mass customization in the context of the lowest income range of social housing and showing potential ways to overcome the identified barriers [12-15], mass customization has not yet been adopted in any cases in this context. This indicates that for the lowest income range of social housing in Brazil, there are still gaps in the literature about the identification of barriers and the alignment of benefits of such a mass customization strategy with the interests of the stakeholders.

The fact that post-occupancy processes are usually not considered in studies of mass customization in housing is also a gap in the literature, especially for the lowest income range of social housing developments in Brazil, which has produced more than 1,500,000 housing units in the last decade [16]. The post-occupancy processes in this social housing context include major geometric changes to the housing units, such as significantly increasing the dwelling's area. How the units are built affects if and how the families can make such changes. Likewise, the intention to allow and facilitate such changes affects how the initial units should be built. Families consider such changes to the units as essential since they seldom have the option of moving, even though their life circumstances often evolve. Therefore, these post-occupancy processes should also be taken into account when considering mass customization strategies for this context. This would allow groups (developers, families, governments, etc.) to maximize the social, environmental, and economic benefits of a mass customization strategy to last over time.

Therefore, this study focuses on how mass customization could be applied in Brazil to social housing developments for the population with the lowest income range to promote better environments for the families and the neighborhoods over time. This research intends to address the identified gaps by analyzing the whole ecology of the system of provision of social housing for the lowest income range of housing programs in Brazil, including the post-occupancy processes, in concert with the possibilities, approaches, and tools of mass customization to indicate directions of how they could be applied in this context to bring lasting benefits to the stakeholders. This research investigates the operational aspects regarding the deployment of mass customization in this context, considering the capabilities and interests of the stakeholders involved, how to maximize the potential for such a strategy being adopted, and ways to benefit the largest number of stakeholders and broader society over time while requiring the minimum changes in policy and regulation. Although this research acknowledges the customization of surface materials and finishes as relevant, it focuses on the spatial needs of the user, as it is the spatial changes to housing units that are most difficult for the users to make and cause the most significant problems. Thus, this aspect is considered most important to customize in this case. While the research analyzes the ecology of the system to determine what would be possible within this context, the benefits of customizing are brought through the customization of individual house design. Thus, the study considers mainly the scale of the house and the changes in processes that could improve the design outcome of individual houses in this social housing context. 
Through the results of this research, for this context, broader considerations can be drawn, including for other contexts as shown in the discussion.

\section{Materials and Methods}

This research is of a qualitative nature; therefore, it takes on the characteristics often present in qualitative research. In particular, this study focuses on interpretation and meaning, in which the researcher plays "an important role in interpreting and making sense of [the collected] data", adopting "practices that embrace interpretation and meaning in context" [17]. What is also relevant is being holistic when considering multiple perspectives and the many factors involved [17]. It starts from the premise that two main factors contribute to the problems that emerge from the evolving built environments in neighborhoods of the lowest income range of social housing programs in Brazil: (1) the need to change and add to the original housing unit given that it often does not satisfy the needs of the user from the outset; (2) the lack of design involved in the creation of changes to the housing units over time. The concepts of mass customization and housing adaptability are considered as significant contributors to the development of solutions that could be applied in this context. The study was divided into four stages, as shown in Figure 1.

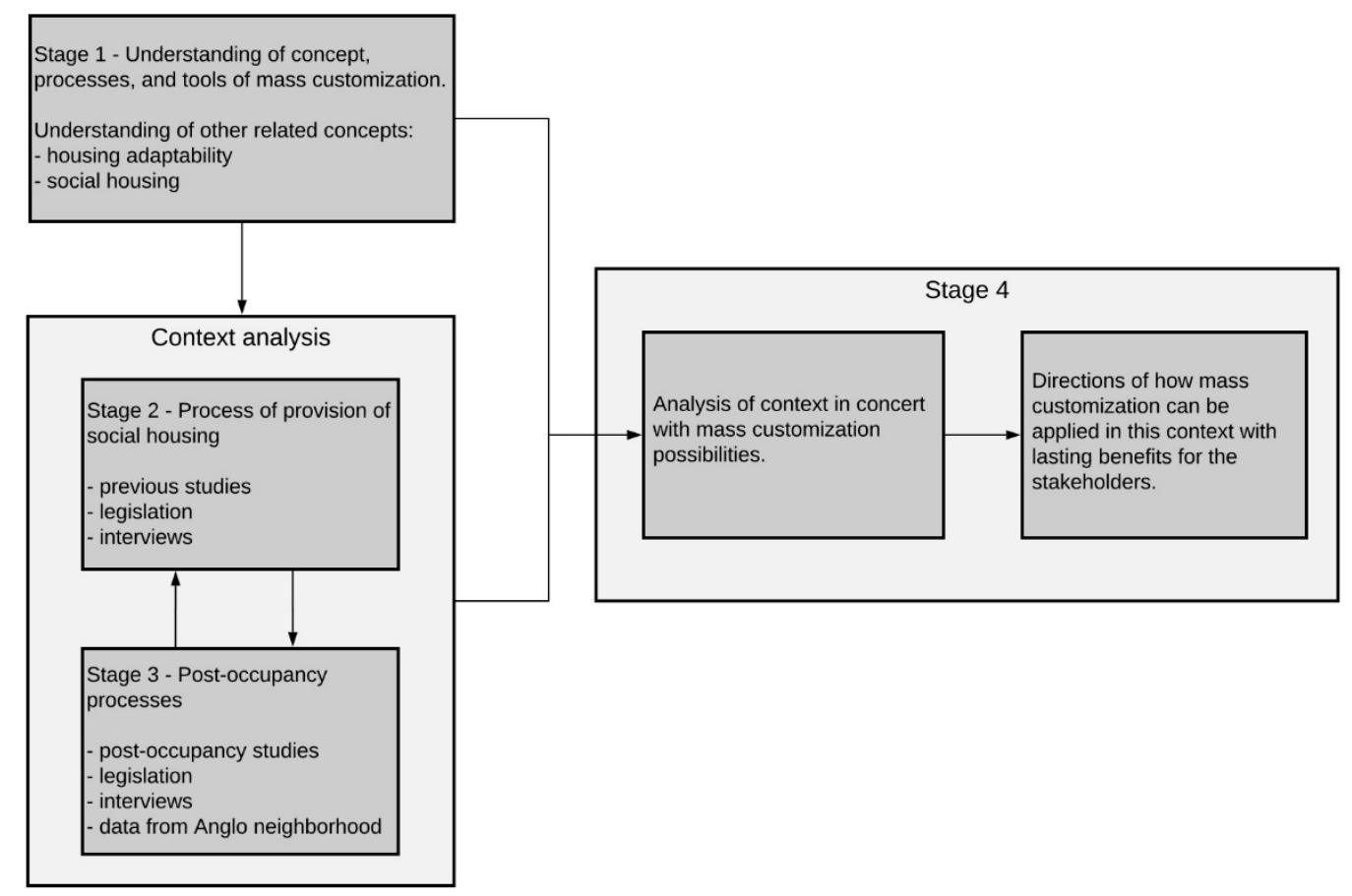

Figure 1. Research stages.

The first stage refers to the understanding of mass customization and its application in housing contexts as well as the understanding of other concepts considered relevant to this research, such as social housing and housing adaptability. The concept of mass customization is used as a guide into processes for the production of individually customized products at prices that "approach, and sometimes beat" those of mass-produced goods [2]. Housing adaptability is used to guide aspects relating to design and technologies, aiming to facilitate a fit between the user's space need and their home, especially being able to change their home after occupancy [18-20]. This stage draws on theoretical references related to the concepts involved in the research as well as previous studies and cases that use and apply those concepts.

The second and third stages refer to the understanding of the context and processes of social housing production in Brazil, focusing on the lowest income range of housing programs. Stage two (shown in Section 3) refers to the process of provision of social housing and stage three (shown in 
Section 4) refers to the post-occupancy processes. In these stages, documentation research also was drawn on, including bibliographies on social housing processes, relevant legislation and policies, and post-occupancy studies. Data from a specific social housing neighborhood, the Anglo neighborhood in Pelotas in the south of Brazil, were also analyzed. These data were made available to the authors by the research group Naurb [21] and include information regarding the specific process for the neighborhood's implementation, from application for funding to completion of construction, and data from post-occupancy studies. The latter included demographic data and the changes made by the families to the housing units.

As one of the objectives is to identify the limitations and potentials present in the current social housing processes in concert with the strategies and tools of mass customization, in some cases, the information available in the literature is insufficient to make these connections. Therefore, this study also draws on semi-structured interviews with key stakeholders. A total of 11 interviews were carried out, divided into six categories of stakeholders. The stakeholders were identified based on the literature about the provision of social housing and legislation. Each person interviewed was also asked to identify other stakeholders they believed were relevant to the process and to be interviewed. Whenever possible, interviews were conducted with more than one representative from each category and from more than one city. These interviews included three city architects and engineers, three city social workers, the owner and manager (also an engineer) of a development company, the national manager for approval of innovative technologies for social housing construction, the regional manager from the financial institution Caixa Econômica Federal (CEF), and two experts in social housing who specifically research processes in the lowest income range of social housing.

The fourth stage refers to the analysis of the specific social housing context and current capabilities of the stakeholders in concert with the possibilities and tools of mass customization with a focus on improving the living environments for the families and the city as the neighborhood evolves. From the results, it is possible to indicate directions of how mass customization could be applied in this social housing context, aiming to improve the living conditions within the unit and the neighborhood as a whole, bringing further benefits to the city as these neighborhoods evolve over time. Relevant considerations from this stage are shown in Section 5.

\section{Process of Implementation of Social Housing Developments}

The process outlined in this section focuses primarily on urban housing in the My House My Life program - translated from programa Minha Casa Minha Vida (MCMV)—since it has been the largest provider of social housing units over the last decade. However, many of the processes and relationships between stakeholders described here apply to other programs too. Furthermore, the interests and motivations of the stakeholders are also maintained across different programs. Most importantly, the solutions in terms of both urban and unit design are also consistent across several different programs, as are the problems they result in and the way the families deal with them in post-occupancy.

Social housing programs aimed at the lowest income range of the population usually produce units that are completely or mostly subsidized by the government. The lowest income range of the MCMV program includes families who earn between zero and up to approximately two times the minimum wage and the subsidies can cover up to $90 \%$ of the cost of each housing unit. Figure 2 outlines the main stages for the implementation of a new social housing development and shows the main operational stakeholders involved in this process. Although there may be some variations from city to city, especially regarding how much time each phase takes, the overall process falls within this structure for most cities. 


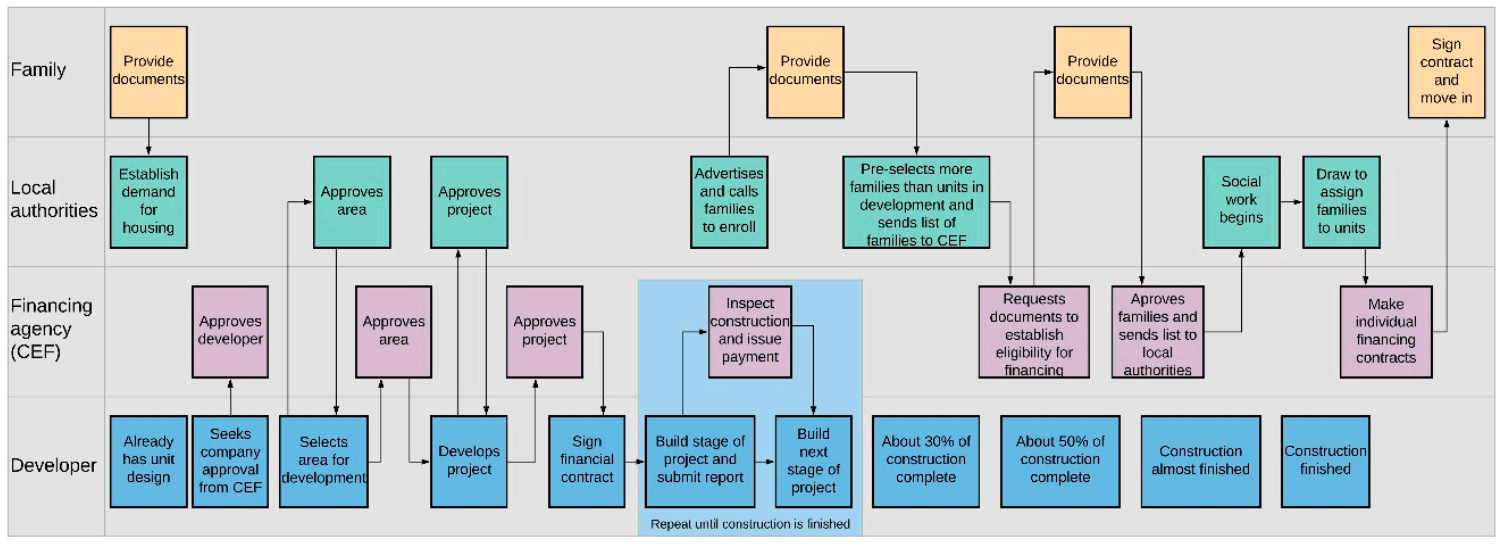

Figure 2. Flowchart of main stages of the process of provision of social housing.

A first step for enabling a new social housing development is registering families who are eligible and interested in receiving a social housing unit. The cities' housing departments usually do this on an ongoing basis. At this point, the families indicate their interest in being considered for a social housing unit and provide the necessary documents to show their eligibility. The local authorities assist the families in registering in the federal government's social programs system (Cadastro Único). The information kept within this system includes identification of each of the family members, their work condition, the family's income, and their living conditions, among others [22]. Information regarding the family's current living conditions is collected during this meeting, both to establish their need for housing and to determine where within the city they currently live.

An initial step taken by the developer is to consult the financing agency Caixa Econômica Federal (CEF) to determine if there is funding available for social housing developments in the chosen municipality. They also seek pre-approval from CEF as a capable company to build within federal programs. This is done to ensure the developer has the financial means to keep construction going since the developer must first build each stage of the construction, foundations for example, with their own capital, after which CEF will verify if that stage is up to their standard to then pay for that part of the construction. Thus, considering the scale of these developments, a considerably large amount of resources is needed to start the process and keep construction going, which smaller companies may not have.

To initiate a new development project, the literature has identified two main distinct possibilities. One possibility is for the city to provide land for the new development and call for interested developers to produce a project. However, the most common scenario is for the city to wait for a developer to show interest in producing housing for this income range. In this case, the developer proposes to the city where they intend to build the new development. At this stage, the process only keeps going if the city authorities approve the proposed land for the new development. This may seem like an opportunity for the cities to have greater control over the locations where developments get built. However, because the cities are dependent on having developers interested in building for this income range, local authorities are often pressured into approving developments in inconvenient areas for fear of losing the interest of the developer [23,24].

The choice of cheaper land on the outskirts of cities-often in areas previously considered rural—and the standardization of design became the norm [23]. When the developer proposes to build a new development for this income range, they usually already have unit designs for varying sizes of lots so no consideration is given to the differences in location, culture, and family composition [13]. This standardization in design leads to several problems, such as poor urban spaces, lack of internal comfort, high energy consumption, and low satisfaction from the users [18,25]. Local authorities, 
pressured by the building companies, in many cases, have made this process easier by changing urban policy, urban perimeters, and local construction rules. These changes were made to allow the construction of developments in rural areas, with reduced requirements of green and public spaces, reduced unit requirements, and reduced taxes for the construction companies $[23,24]$. The ministerial ordinance Portaria No 660 [26] is the national regulation that establishes the minimum standards for housing units and urban parameters for projects within the MCMV program and any other program that uses federal funds. It is often the only regulation followed for design purposes since projects cannot be funded if this regulation is not followed; however, it is usually less restrictive than local urban and building codes. Thus, developers often seek special approval within the city for the project to comply only to the program's standards. For house units, the program's regulation establishes a minimum of $36 \mathrm{~m}^{2}$ and that every housing unit must have at least two bedrooms, a kitchen, a living room, a bathroom, and a laundry area.

Once the developer has the city approval, they submit the project for approval with CEF. Different from the approval from the city, CEF analyzes the proposed budget for the project and whether the percentages of the total funding designated to each stage of the project are within the permitted standards. Once CEF approves the project and the contract between CEF and the developer is signed, then construction can begin. It is important to highlight that the total amount paid for the development is capped based on the number of units and the relative regional importance and size of the city. Therefore, one way to maximize profits is to save as much as possible on aspects of the budget that are not determined by quantity, such as the amount designated to design the development. Furthermore, having the cost of the land as part of the financing process also benefits the developer since they receive this amount at the start and can often negotiate to pay the previous owner in instalments over time, therefore leaving a significant portion of the amount received for the land to be used to start construction.

Although the city approves the final design of the development, it is difficult for the municipality to demand quality in design considering that they cannot deny approval if the project is within the legislation [27]. This was corroborated through interviews with city workers who state that the role of the city regarding the design is limited to checking if it complies with the legislation. This aspect can be a barrier to quality in design considering that the legislation was highly simplified to facilitate the fast approval of projects and that, in the MCMV program, the municipalities are expected to release barriers and facilitate the action of the private sector [27].

Many reasons can lead to delays during construction. An example includes a site inspection determining that a particular stage of the construction is not up to the standard required by CEF and that some aspects need to be redone. This means that the construction company will not receive the amount designated for that stage until it is redone. Depending on the company's resources, this can mean that the rest of the construction stops until they receive that amount. There are cases in which the resources necessary to bring the construction up to the established standard were too high and led the company to bankruptcy. In these cases, construction stops for longer, until another company can be hired to finish construction, usually with an updated cost estimate which increases the final cost for the development. However, construction can also be delayed for other reasons, such as public authorities requiring that construction stop to review specific permits and taking longer than usual to review them. In such cases, if the prices for construction change significantly, the company can apply to update the cost estimate. Thus, it is not uncommon for this kind of development to end up costing much more than what was the original budget and taking much longer than the original schedule.

When construction is about $30 \%$ complete, the city's social housing department starts the pre-selection of families [13]. In some cases, part or all of the housing units may be reserved for families that the city is removing from informal settlements in risk areas, for example. At this point in the process, social workers may use different means-such as interviews with families and visits to their current home- to make a social report. With this report, the city ranks the families according to national and local criteria and selects families to continue the process to receive a unit in the specific 
development. The number of families selected to continue the process is equal to the number of units the development will have plus 30\% [28]. The city sends this list of pre-selected families to CEF when construction is about $50 \%$ complete [28]. CEF does their own analysis of the documentation to determine which families are eligible for financing. With this updated list of eligible families, the city informs the families that have been selected to receive a unit. However, at this point, the families have not yet been assigned to a specific unit.

Every social housing development, regardless of the program that led to its implementation, must include funds for social work with the families, which is governed by the ministerial ordinance Portaria No 21 [29]. By knowing which families will live in the development, the pre-occupancy social work with the families can begin. This consists of working with the families to prepare them for formal housing and living in the new community. Most often, the families selected for a development come from different areas around the city. The social workers help them create a community association and carry out educational actions regarding things such as how to deal with their garbage, how to save energy, what is acceptable or not in public spaces of the neighborhood, among others. Preparation and support are also given for the families to apply to other social programs when that is the case and things such as finding and enrolling children in a new school. This social work continues for at least one year after the families move to the new development.

When construction is practically finished, and in some cases after it is finished, the city calls the families for the draw of units. This is a draw to establish which family will receive which unit. The updated list of families with their designated unit is then sent to CEF, which makes the individual contracts of the financing process for the families to sign. Although each family signs their contract individually, cities often wait until all the families have signed the contract to give the families the keys to their units all on the same day in a highly publicized event. The beneficiary family must live in the housing unit for ten years of the financing process in order to receive the subsidy. If the family wishes to settle the remainder of the debt beforehand (to sell the unit, for example), then they must pay the total that is still owed without receiving the subsidy (which can be up to $90 \%$ of the total cost of the unit). However, illegal sales do still happen.

\section{Post-Occupancy Processes}

\subsection{The Need for Change}

Specifically for this social housing context, Brandão [18] indicates that the following aspects frequently appear in post-occupancy studies as motivators for change: aspects related to function, such as the layout and size of the rooms; the size of the housing unit; aspects related to visual and auditive privacy; aspects related to personalization and definition of territory; changes in the family, such as the size of the family; economic and educational level. Thus, most reasons for making spatial changes in this context fall under the categories identified by Friedman [19]—family transformations, fitting new technologies, and affording in stages—and, therefore, are similar to other contexts. However, how these aspects appear and motivate changes to the housing units in this context can have some specific factors not considered elsewhere.

The initial size of the housing units is a crucial factor perceived by the families as needing change. In a study regarding the perception of the users in three different social housing developments, the authors indicate the main reason for wanting to leave the development was the inadequate size of the unit; however, in one of the three developments, which consisted of house units, the possibility of expanding was seen as a positive factor [30]. The aspect of fitting new technologies is often identified in relation to the size of the unit. This does not necessarily mean that the technologies changed since the unit was initially built, but often, the initial unit already did not consider the technologies available at the time it was built in order to minimize the size of the unit. This is a common complaint by families concerning washing machines, for example [31,32]. Although it is not a new technology, most of the social housing developments do not include a space in the unit for this equipment nor the necessary 
plumbing to facilitate its use. Similar complaints are also seen in relation to space and electrical outlets available in the kitchen.

The aspect of family transformation is also a significant motivator for spatial changes to the unit. This occurs with normal changes to family through time, but, similar to the technologies factor, the family does not necessarily need to change for the original unit to become inadequate. In many cases, as a result of standardization in design, the original unit is already inappropriate for the size or arrangement of the family when they first move in. In a post-occupancy study, Jorge et al. [32] identified that $40 \%$ of the units had six or more people living in them. Furthermore, it is also common to have extended family living in the same housing unit. In the same study, this was the case in $30 \%$ of the housing units [32]. Another important factor to consider regarding adapting the unit to changes in the family refers to the work conditions of the families. It is common for the family members to have informal work conditions that is, having an unstable source of income. Thus, initiating and running a small business from home is common in these developments and even encouraged given that workshops for this purpose are provided as part of the social work. This kind of activity often requires space beyond the original unit, thus also being a significant driver of spatial changes.

Affording in stages is also an important aspect to consider in this context. While it is not a reason for change, it significantly influences how change happens, as discussed in the next section.

\subsection{How Change Happens}

In house units, it is expected that families will make changes and expand their unit after moving in, with the possibility of expansion even required by current legislation [26]. Furthermore, many of the interviews done for this research, with architects, engineers, and social workers, had similar statements saying that for house unit neighborhoods, it is unavoidable that the families will expand the units even when it is not allowed. However, because the units are not built with adaptability in mind, it is even more expensive and difficult for the families to make these changes [23]. Most of the changes are carried out illegally by the homeowners themselves. This includes planning what to change and the construction itself.

It is common for the family to start buying construction materials in small quantities from local, often small, building materials stores and building the extension themselves, a small portion at a time. This process continues over time until all the intended expansion is complete. Thus, it is common in these developments to see partially built rooms, such as the outline of a room built to only half the height, or a space with one wall and the roof, which is used as a veranda until the other walls can be built. It is also common to use temporary materials, such as plastic and plywood, as parts of the walls until they can afford a more permanent solution. Another common scenario is for the family to buy all the necessary materials over time, storing it until they have enough to build the entire intended expansion and then building it very quickly. The storage of materials is usually done in the garden or in front of the house on the street, which can implicate some losses due to weather or theft. Often, neighbors, family, and friends also help with the construction. Hiring a resident of the neighborhood who works with construction is also seen in some cases. Therefore, the aspect of affording in stages does not only refer to expanding when they can afford it but also to dividing an intended expansion into stages distributed over time.

Several post-occupancy studies $[18,25,31-33]$ have demonstrated the changes that families make to their housing units in social housing developments. These studies categorize not only the changes made but also why they were made. Previous authors identified four main categories of reasons associated with the changes made by the users: safety, such as building a wall and adding bars to windows; family need, such as building a pantry or new bedroom; size, such as adding or increasing the area of rooms such as the bedroom, bathroom, and kitchen; finishing, such as changing the windows and the wall finishes, e.g., substituting paint for ceramic tiles [33]. It is important to note that, in that study, the reasons of 'needs' of the family and 'size' account for similar changes, referring to spatial changes, and, in many cases, appear together. These authors further indicate that most changes are 
made due to the dimensional inadequacy of the spaces to their functions and the domestic needs of the occupants [33]. This is consistent with findings from other studies that indicate that for social housing, the most pertinent kind of change is expansions [31]. This author analyzed several social housing developments, indicating the following changes as most frequent:

- Intervention on the façade, including building a wall;

- Adding a garage;

- Increasing the area of the kitchen;

- Creating or increasing the area of the laundry;

- Creating a separate space for business, studies, or hobbies;

- Creating more bathrooms;

- Creating more space for storage;

- Changing the relationship between the kitchen, area for meals, and living room;

- Adding one more room.

These changes are consistent with those shown in other post-occupancy studies [18,25,32-34].

Specifically referring to spaces for business, several post-occupancy studies show that it is a significant driver of renovation; in some cases, having a space for business was considered important by more than $60 \%$ of the families [32]. Although this does not necessarily require changes to the units, often it is reflected in the significant amount of cases in which a room for business was added to the units. Likewise, adding a garage is very frequent in cases in which it is possible to expand to the front or side of the unit. In these cases, the garage and business sharing the same space is also common.

An important consideration that is consistent across many post-occupancy studies refers to the order in which changes to the units are made. Changes that are made immediately after the families move in are more related to demonstrating territoriality and differentiating themselves from the neighbors. These include placing significant objects in the front of the house, planting a garden, and changing the color of the façade. These being the first changes made is understandable given the importance of the feeling of ownership towards the unit and the low cost involved in making them. Other changes that are often made before spatial changes in the unit are related to safety, such as building walls around the lot.

Regarding spatial changes, the studies indicate that increasing the area of the kitchen is often a priority and, usually, it involves increasing the area of the unit. Expansions of other spaces or adding other spaces to the unit appear as the second change made or the second most frequent first change. Several studies highlight the significant amount of cases in which walls with pipes (such as the bathroom and kitchen) had to be demolished and rebuilt elsewhere, making the changes more difficult and expensive than necessary and highlighting the need of carefully placing these elements in the original unit design $[25,32,33]$.

It is important to highlight that while the categories of expansions are consistent across many different developments, the solutions for the expansions (for example, where the expansion is built) vary considerably. Not only it is dependent on the original unit design and where there is room to expand, but the solutions also vary within the same development of equal units. Even when an expansion plan was provided, there are many cases of the families not following such a plan. Some of the reasons for this include the plan not meeting the family's needs or for economic reasons [34].

Another important aspect to consider refers to how long after moving in the changes are made. Several studies conducted up to five years after the completion of the development already show significant changes made to most units. In the Anglo neighborhood, completed in two stages, four and two years before the data collection, $80 \%$ of the units already had changes made [32]. Even in an older neighborhood, the authors show that most changes $(70 \%)$ were made within the first three years after moving in [33]. However, it is still relevant to consider that older neighborhoods present more expansions; this shows that there is continual transformation of the houses over time, even if it does slow down. 


\subsection{Problems with Changes}

In most cases, the families perceive the changes as beneficial and as an improvement in their living conditions. However, these changes often result in inadequate situations, such as encroaching onto the public space, having no ventilation and lighting, blocking off windows of the initial unit, inappropriate discharge of rainwater, dangerous stairs, and opening windows directly onto the neighbor's lot, among others $[18,25,31]$. These inadequate situations can result in negative consequences not only for the families but also for the city, such as increasing health problems and the burden on the city to provide health care and limiting the city authorities' access to public services, such as public lighting, provision of electricity, and water and sewage, for example. In one case reported during the interviews, expansions were built over the water drainage system. This resulted in frequent flooding inside the houses due to a lack of maintenance of the system. In the city of Pelotas, in an older social housing neighborhood, several families built onto the sidewalk enclosing the public electrical posts; currently, access to most of the public lighting and distribution by the local authorities is difficult. Figure 3 shows cases from the Anglo neighborhood that also encroach onto the public space, eliminating the sidewalk. Initial construction for this neighborhood was completed in 2014.
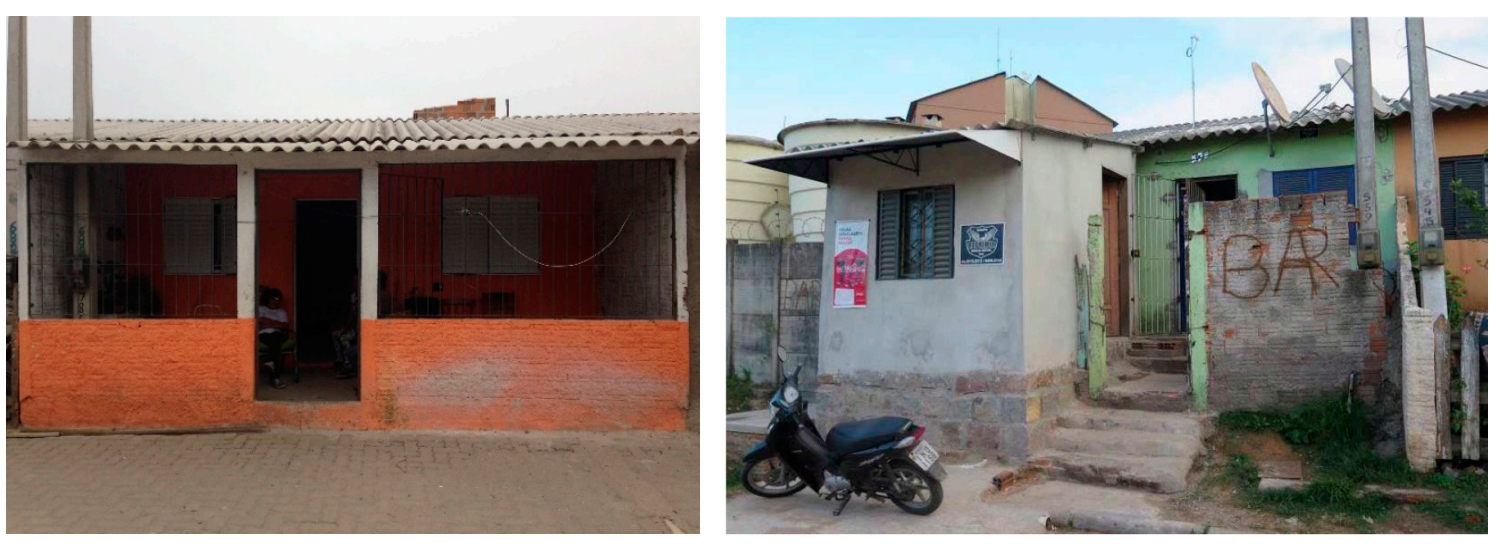

Figure 3. Example of expansions encroaching onto the public space. Images courtesy of NAUrb-UFPel [21].

Referring to self-construction in informal settlements, Estevão and Medvedovski [35] indicate the inadequacies related to humidity as one of the main factors in which the housing environment can be problematic to the health of the inhabitants. Self-construction in formal social housing neighborhoods shows several of the same risk factors. Several authors highlight the lack of natural light and ventilation as a frequent problem resulting from the expansions in social housing neighborhoods [25,32,33]. One of the most problematic situations from such a scenario is that it aggravates health problems resulting from humidity, such as respiratory and skin problems [35]. Furthermore, it often leads to a lack of thermal comfort, which, as well as aggravating existing conditions, such as hypertension [35], can lead to excessive use of energy to mitigate the condition.

Another factor refers to situations of risk to the physical integrity of the inhabitants. The inappropriate proportions of stairs and the use of ceiling slabs as an extension of the house are responsible for an unimaginable number of serious accidents [35]. These situations are also common in self-built expansions in social housing neighborhoods. An example of inappropriate proportions of stairs can be seen in Figure 4. 


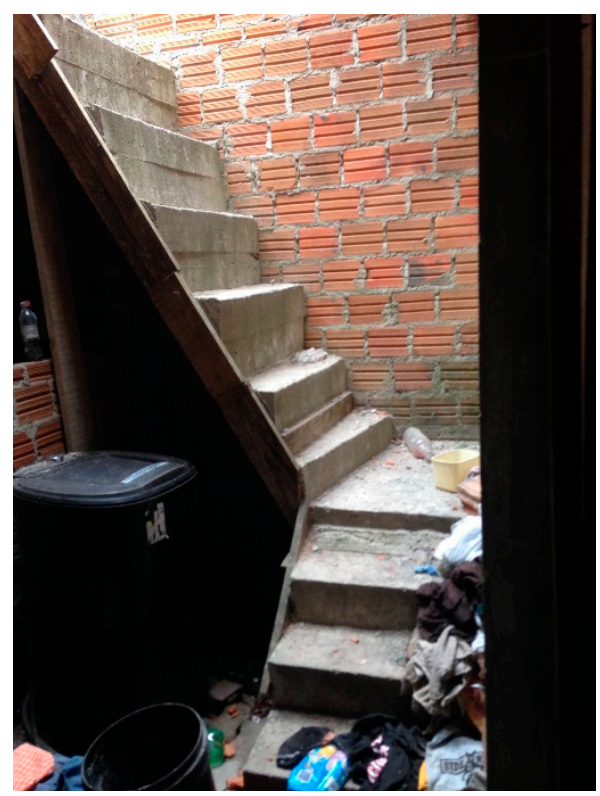

Figure 4. Stairs in the Anglo neighborhood in Pelotas. Image courtesy of NAUrb-UFPel [21].

In some cases, the expansions reproduce the logic of precarious housing in which the families lived before-for example, building rooms or walls with temporary materials or accommodating a second family on the same lot without a bathroom; this creates a cycle that threatens the condition of a healthy environment and increases the risk of disease contamination [32]. However, from post-occupancy studies, it is possible to indicate that despite the families' low-income situation, many of them invest significantly in expanding their units in a permanent way. Figure 5 shows an example from the Anglo neighborhood, which increased the area on the ground floor for a garage and business and added a second floor. Furthermore, it is important to highlight that the changes made and how they are made is consistent in many post-occupancy studies in such developments from different cities and built through different programs.

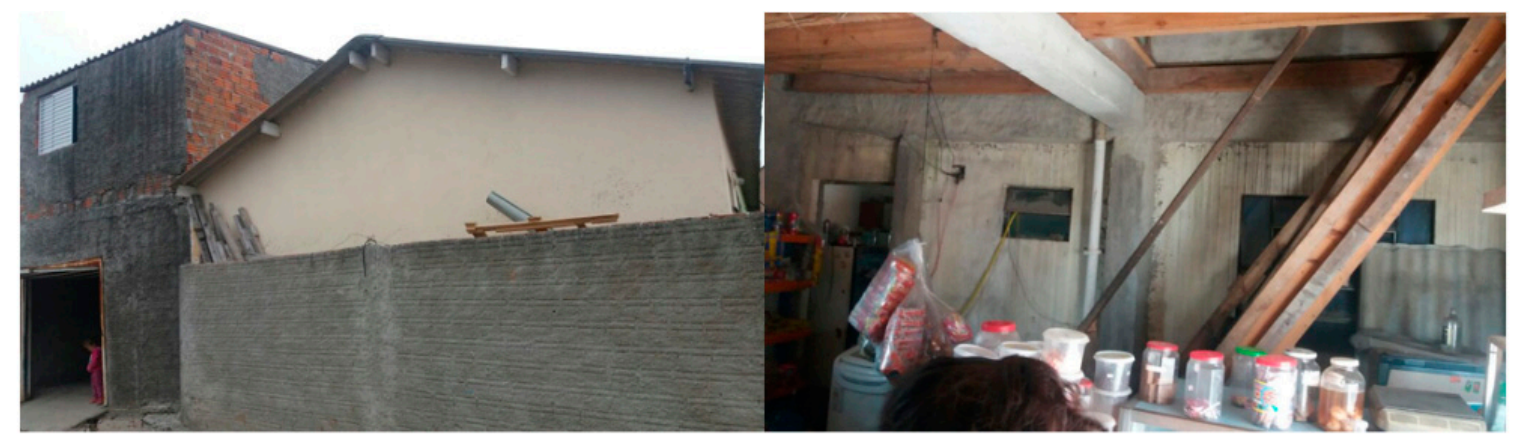

Figure 5. Example of housing unit with expansions. Images courtesy of NAUrb-UFPel [21].

As previously explained, many of these changes bring problems that have an effect beyond the family that lives in the unit. However, very rarely are any actions taken to support the families in making better decisions in their expansions or to discourage problematic situations. Many municipalities have in place legislation with mechanisms to allow the municipal authorities to notify, fine, and, in some cases, demolish illegal constructions, such as those that encroach onto the public space, for example. However, these mechanisms are seldom used. Giving a notification when this kind of illegal construction is identified is the action most used; however, these are usually ignored and no further action is taken. When questioned about this scenario, several of the stakeholders interviewed attribute it to political 
will. They highlight that local politicians fear looking bad for allowing more severe action to be taken 'against' this vulnerable population.

It is important to consider that given the opportunity to have assistance for these expansions, often, families will seek it, as there is significant demand for this kind of assistance from the very few organizations that provide it free of charge for these families. An example of such organizations are the university outreach offices called "Model Offices" (Escritórios Modelo in Portuguese), which are present in some architecture schools. There are several benefits for the families in having their houses regulated within the municipality; one that is immediately perceived by the families is the possibility of being able to apply for financial assistance for further construction. The benefits which the families themselves might not see immediately, such as avoiding health issues, are equally important and in the best interest of the city as a whole.

This need to assist low-income families in design and construction was recognized by the federal government in 2008 when specific legislation was approved, stating that low-income families should have such assistance without being charged for it [36]. However, there are few examples of municipalities and other entities that provide such assistance for improvements to individual housing units. This is understandable since the costs for professionals to work individually with each family are high and the funding is limited. Moreover, in cases where such technical assistance is available, it is usually only for families living in informal settlements, not for families in social housing neighborhoods. This also is understandable since the latter are considered as already adequately housed and it would not make sense to spend limited public funds twice on the same family when there are others in need. However, there are significant funds destined for social assistance, specifically for these social housing neighborhoods. Thus, if costs could be reduced from having a professional work individually with each family, it would be feasible to provide such assistance as part of the initial funding for the development and other social assistance programs that take place within these neighborhoods.

\section{Discussion}

This section discusses the implications of some of the exposed social housing processes in concert with the possibilities of mass customization.

A vital consideration refers to how public authorities view social housing production. Through legislation and practices, it is clear that the initial housing unit is seen as the final product. All the legislation regarding the production of social housing units refers to the process as finished once the construction of the unit is complete. Post-occupancy social work is the only thing that goes beyond the finalized construction of the initial unit and it does not consider further construction. In contrast, for the families, the initial house unit is seen as a starting point from which they continue to build. As the neighborhood evolves, the self-designed and self-built additions to the units often bring unintended negative consequences along with the intended benefits. The legislation regarding technical assistance in housing design is broad enough that it could include social housing developments. However, it is not seen in practice as applicable in these cases. Pre-occupancy construction, post-occupancy renovation, and technical assistance are organized and seen as completely separate processes. Thus, one happens without any consideration of the other. However, when considering the limits of the initial production of social housing and the needs of the families over time, it becomes clear that for social housing developments, it should all be seen as part of one continuous process, including for funding purposes. Broadening the context considered for the use of funds can lead to a more efficient allocation of those funds [37].

This is particularly relevant when considering mass customization for this context. Previous studies have indicated that small changes in the current process of provision of social housing could create opportunities for mass customization of the initial units [14]. However, by including the post-occupancy processes in the analysis of potential mass customization possibilities and benefits for this context, it is possible to indicate that customizing the initial unit is not the most sustainable option 
as it may not have lasting results in terms of satisfying the families' needs and avoiding problematic situations over time.

An important consideration is that mass customizer companies usually profit by attracting more customers with customized products, gaining their fidelity, or taking advantage of their willingness to pay a premium for a custom product [2]. However, these options are not available in this social housing context. The amount the company can receive per unit is capped and the families do not have a choice of developer-they are assigned to a unit by the city. Stakeholders from different spheres of government are more interested in a higher number of units built than higher quality in design. This appears in all publicity, and even official program websites state that priority will be given to proposals that reach a higher number of families [38]. Therefore, the companies still would not be motivated to mass customize, even if the added effort and cost were only marginally higher.

Regulations around the numbers and types of rooms that the units must have, combined with the restricted floor area to keep the costs low, mean that there is very little that can be customized in terms of the families' space needs. Although these regulations are necessary to establish a minimum standard, they can also be a barrier to mass customization. Furthermore, most changes made to the housing units post-occupancy add area to the house. This shows that in most cases, a large part of the reason for the unit not satisfying the families' needs refers to it being too small. This aspect would still be present even if the initial units were customized. On a different approach, the initial area of the housing units could be increased, making it more meaningful to customize them. However, this would require significant changes in the current process of provision, especially increasing funding. Therefore, this is not a feasible option. Investing in flexibility could be a way to allow for the families to satisfy their needs after occupancy better, while still building all initial units equal within current regulations. However, the way the families currently change and expand their units also leads to problems for themselves, the neighborhood, and the city. Thus, providing assistance for the families in this renovation process is necessary. It is also important to highlight that the needs of the families change over time. Thus, having a strategy to customize the initial unit and not addressing this as a process over time could still lead to the same problems, especially with the expansions.

This study argues that it would be more feasible and have a higher potential for bringing significant benefits over time-not only for the families but also to the city and other stakeholders-if a mass customization strategy were applied with post-occupancy differentiation. This way, the initial units built could still be small and equal within the development, not requiring significant changes to current social housing programs, their associated policies, and the capabilities of the stakeholders. Post-occupancy, the families would use a mass customization configurator, a co-design system, to interact with and visualize the design of expansions for their homes. Such configurators have the capacity to validate the customer's solutions, including in cases that involve spatial aspects in housing design, as shown by previous authors $[7,8]$. Only solutions within the legal parameters for the city would be validated. The design validated by the configurator could receive automatic approval by the city. This would significantly benefit the families and the city by avoiding problematic changes to the units. The families would have the opportunity to manipulate and visualize different design solutions and receive feedback before engaging in construction.

Providing this assistance to the families to have validated design solutions could also serve as a justification for cities to take more severe action, such as fines and demolitions, towards problematic construction situations. The interviews done for this research indicate that there is currently a perception that any actions taken in this regard would be hurting an already vulnerable population and, thus, that such actions are not socially acceptable. This perception is intensified by the fact that most cities do not offer an alternative to the current practices of self-design and construction, making it morally and politically challenging to take serious action against such illegal construction. However, if processes such as those proposed in this study are in place and design assistance is available to the families, then it would be a choice of the family to ignore such help and build problematic solutions. This could remove some of the perceived barriers around taking action to correct problematic situations; 
for example, demolishing construction that encroaches on public space. In other words, if the city is providing the conditions for families to build legally and these families still choose to build illegal solutions, then it could become socially and politically acceptable for the city to fine or demolish such problematic solutions.

To allow post-occupancy differentiation as easily and as much as possible, increased adaptability of the initial unit is essential. Most cities do not have the resources to critically evaluate and suggest design changes during the approval process of new social housing developments, with city authorities limited to checking for compliance with legislation. One of the results of this limitation is that most projects merely achieve the minimum required by legislation. In terms of adaptability, the regulation has one sentence that states that the housing unit shall be designed to enable its future expansion without loss to the lighting conditions and natural ventilation of the existing rooms [26]. Given that this regulation provides little guidance, it is usually fulfilled by showing that one room can be added. Often this means that the unit was designed to allow only one room, in a specific place, to be added. This is not enough to satisfy the amount and variety of changes the families need.

In contrast, several researchers have developed extensive adaptability guidelines specifically for social housing. However, most of such guidelines depend on subjective design judgment, making it difficult to incorporate in regulation and to check for compliance. Although changing the way projects are approved in cities to include their design interests and feedback would be ideal, it is currently not feasible for most cities; thus, providing such thoughtful feedback is outside their capability. An option that could help include more adaptability in design would be to include guidelines in the regulation of the program in a way that would make compliance to them easy to check. One way this could be done would be to use the adaptability guidelines developed in previous studies, for example, by Brandão [18], but translating them as much as possible into quantifiable acceptable ranges that are easy to demonstrate. For the project to be approved, the developer would then have to demonstrate compliance to at least three of the guidelines in addition to the one already in the regulation. Table 1 shows a selection of guidelines that would be feasible to implement within the regulations of the MCMV program and could be checked easily within the current process of approval. The table also shows possible wording for the regulation, such that it would be easy to demonstrate and check for within the approval process. Figure 6 shows an example floor plan inserted in the existing lots of the Anglo neighborhood that was developed in this study following such guidelines. The walls with pipes and structural columns are shown in gray, and the houses are meant for semi-detached typology. Figures 7 and 8 demonstrate some of the expansions possible with this design, which significantly increase the area of the house, demonstrating the design's compliance to the guidelines in Table 1.

This study proposes that the main agent of the mass customization strategy, in this case, should be the local authorities and not a company as in most mass customization cases. This would allow the city to have more power over the parameters to be validated within the configurator and a building system to be used, also making automatic approval feasible. Furthermore, local authorities are more motivated to keep in mind the best interests of the families and the city and could also incorporate the use of the configurator in post-occupancy social assistance within its current format.

To maximize the potential of such a mass customization approach to bring benefits over time, it is essential to consider the families' current post-occupancy processes. For example, distributing the costs of construction over time and being able to self-build to save even more money are important aspects to be maintained. This has direct implications regarding construction for the mass-customized product. For example, pre-fabricating entire rooms to be combined on-site would not be a feasible solution. Pre-fabricating panels that can be combined, allowing families to build at their own pace, as well as using materials that are familiar to them, would be more feasible. Having the local authority as the main agent would also allow several construction companies to be linked to the strategy to fabricate the necessary components. 
Table 1. Adaptability guidelines.

\begin{tabular}{|c|c|c|}
\hline Guideline from Brandão [18] & $\begin{array}{c}\text { Proposed for Writing in } \\
\text { Regulation }\end{array}$ & How It Could be Demonstrated \\
\hline $\begin{array}{l}\text { Set the height of the ridge } \\
\text { suitable for expansions. }\end{array}$ & $\begin{array}{l}\text { Set the height of the ridge at a } \\
\text { height that allows adding rooms of } \\
\text { at least } 2 \mathrm{~m} \text { in length, continuing } \\
\text { along the slope without needing to } \\
\text { change the angle of the roof. }\end{array}$ & $\begin{array}{l}\text { Include, in architectural drawings, a } \\
\text { section showing the added room with } \\
\text { the expanded roof maintaining the } \\
\text { same angle and complying with the } \\
\text { minimum heights within the room. } \\
\text { Example in Figure } 8 .\end{array}$ \\
\hline $\begin{array}{l}\text { Allow the creation of new roof } \\
\text { slopes without affecting the } \\
\text { functionality. }\end{array}$ & $\begin{array}{l}\text { Allow the creation of new roof } \\
\text { slopes without affecting the } \\
\text { functionality. }\end{array}$ & $\begin{array}{l}\text { Include architectural drawings with } \\
\text { the new roof slopes. }\end{array}$ \\
\hline $\begin{array}{l}\text { Separate, if possible, structure } \\
\text { from walls. }\end{array}$ & $\begin{array}{c}\text { Separate structure from walls, } \\
\text { such that the walls are } \\
\text { non-load-bearing. }\end{array}$ & $\begin{array}{l}\text { Highlight, in the architectural } \\
\text { drawings, the separation between } \\
\text { load-bearing elements and } \\
\text { non-load-bearing elements. Include } \\
\text { the loads used to calculate the } \\
\text { structure. Example in Figures 6-8. }\end{array}$ \\
\hline $\begin{array}{l}\text { Prepare structure to receive } \\
\text { one or more floors. }\end{array}$ & $\begin{array}{l}\text { Prepare structure to receive one or } \\
\text { more floors. }\end{array}$ & $\begin{array}{l}\text { Include, in the plans submitted for } \\
\text { approval, as well as all the structural } \\
\text { elements included to allow more } \\
\text { floors, the loads used to calculate the } \\
\text { structure and foundations. }\end{array}$ \\
\hline $\begin{array}{l}\text { Provide permanent walls with } \\
\text { pipes. }\end{array}$ & $\begin{array}{l}\text { Place walls with pipes in such a } \\
\text { way that the kitchen and other } \\
\text { rooms can be expanded and that } \\
\text { other rooms can be added without } \\
\text { needing to destroy such walls. }\end{array}$ & $\begin{array}{l}\text { Include drawings of the expanded } \\
\text { rooms around the walls with pipes } \\
\text { and of added rooms showing that } \\
\text { those walls do not need to be } \\
\text { destroyed. Example in Figure } 7 .\end{array}$ \\
\hline $\begin{array}{l}\text { Provide setback which allows } \\
\text { expansion to the front. }\end{array}$ & Provide setback of at least $2 \mathrm{~m}$. & Shown in drawings. \\
\hline $\begin{array}{l}\text { Adopt broader front for } \\
\text { individual sites, if possible. }\end{array}$ & $\begin{array}{l}\text { Adopt front for individual sites of } \\
\text { at least } 7 \mathrm{~m} \text {. }\end{array}$ & Shown in drawings. \\
\hline
\end{tabular}

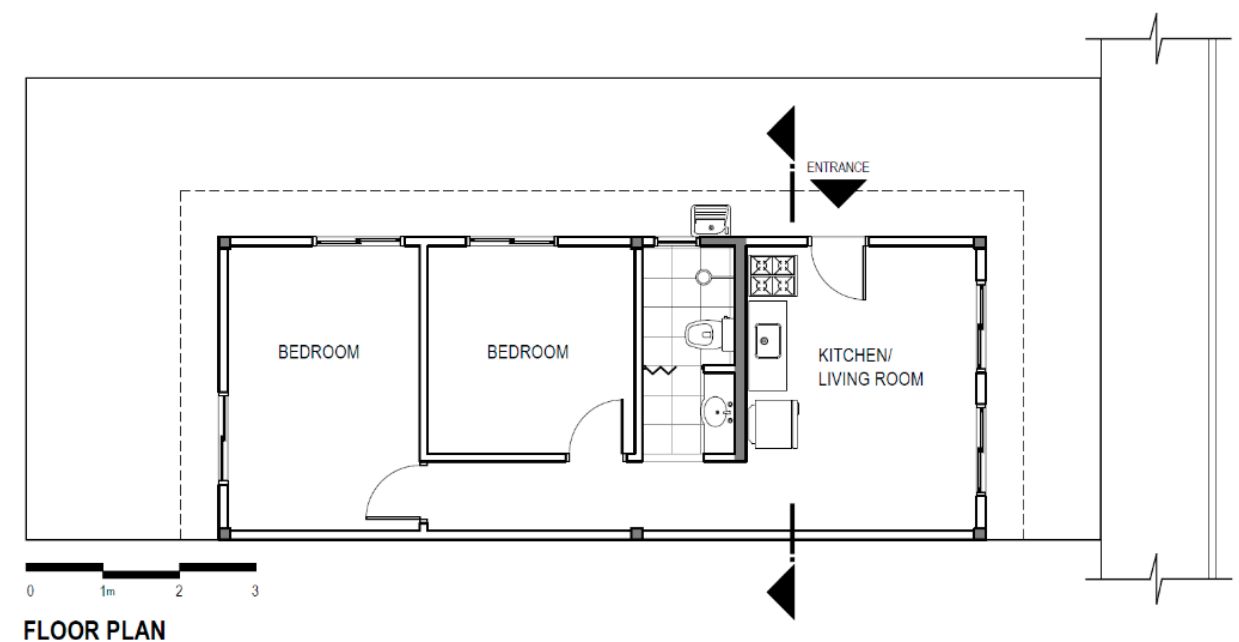

Figure 6. Floor plan of an example unit considering the guidelines for adaptability. 


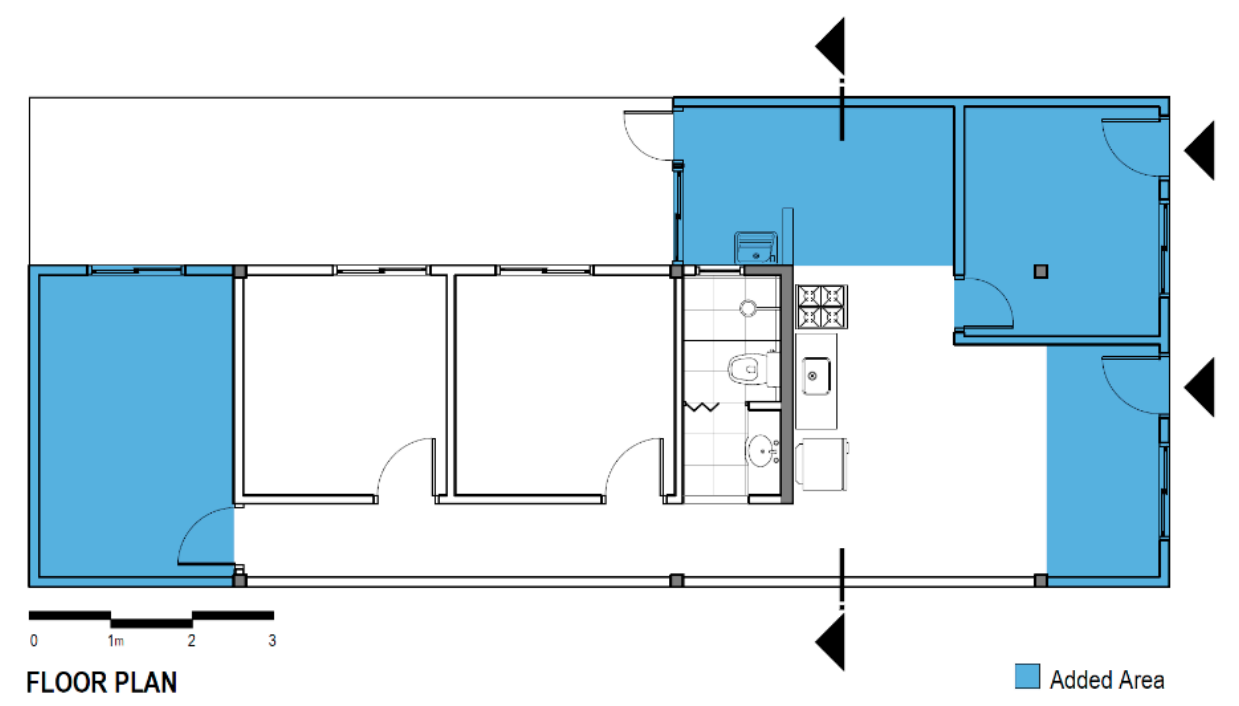

Figure 7. Floor plan of an example unit with expansions, adding several rooms without the need to destroy walls with pipes from the original unit.

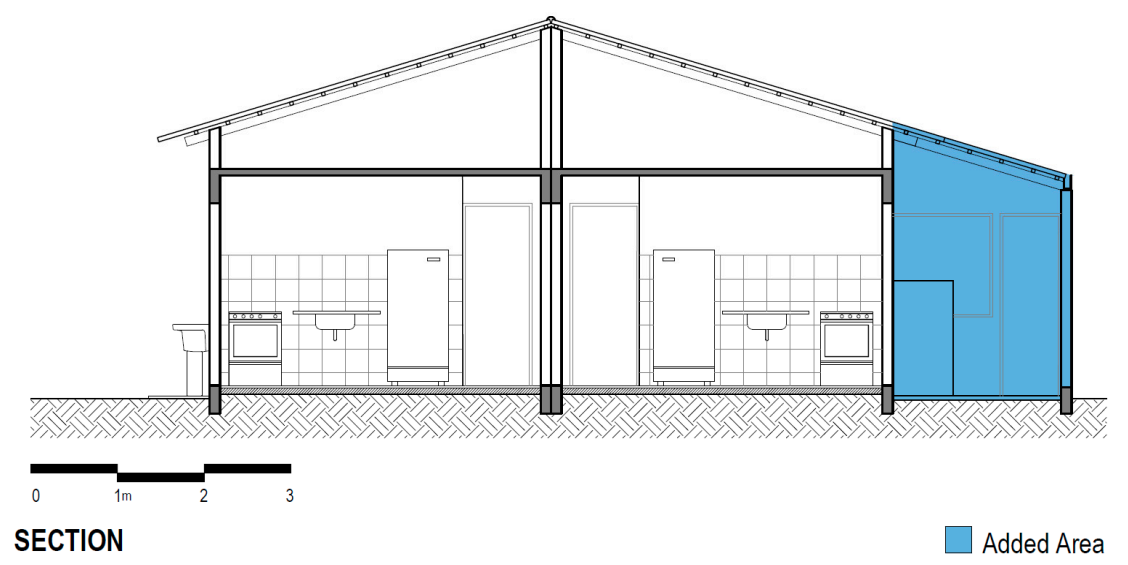

Figure 8. Section of two semi-detached example units. The unit on the right shows an expansion along the slope of the roof maintaining the same angle.

Although this study refers to a specific context, applying mass customization with post-occupancy differentiation could be valuable in many other housing contexts. The aspect of the initial unit not being seen as the final product could be easily extended to other housing contexts. In some cases, it may even be easier to overcome some of the challenges faced in the context considered for this study. In North America, for example, lighter building systems, such as wood-framing, are widely accepted. Furthermore, pre-fabrication within those systems is more widely available. As in some examples shown by Smith [39], a company may seek local pre-fabrication options close to each of the sites where they build to keep the costs low. This could be an opportunity for companies to provide an initial small affordable unit combined with a mass customization system of co-design and prefabricated parts or panels of the same building system that the user continues to engage (buy from the company in this case) over time at their own pace.

Aspects of dimensional or geometric co-design in housing are also relevant to discuss. It has been shown that an aspect that can add value to mass customized products refers to the satisfaction of the customer in perceiving themselves as the creator of the product, the "I designed it myself effect" [40]. However, design complexity and substantial investment in the product have shed doubt on whether this factor can be considered in housing. One of the reasons for dimensional mass customization of housing not being more widely available refers to the customers not having enough confidence or knowledge 
to take responsibility for the design of their homes; thus, it refers to social and cultural reasons and not technological limitations [5,41]. Many people would prefer to buy the house they perceived as professionally designed, even if they had the option of co-designing. Counteracting this is the need imposed by the context within the lowest income social housing scenario. Many post-occupancy studies $[25,32,42]$ in this context have demonstrated the users' willingness to design their own homes, given that the alternative is not building. Thus, with the use of a co-design system, the resulting designs may still be perceived as more 'professionally designed' than the alternative.

Given the contextual conditions, these social housing neighborhoods could be the ideal place to begin the adoption of such geometric co-design processes, given the reduced emphasis of those social and cultural factors considered as significant challenges to the broader adoption of geometric mass customization in housing. Seeing such processes and their results within this context could be encouraging for developers to adopt geometric co-design in other contexts. Furthermore, it could also be encouraging for the users in overcoming some of their insecurities with what they may perceive as self-design.

\section{Conclusions}

A significant contribution of this study refers to the evaluation of the possibilities from mass customization in concert with the broader context and interests of the stakeholder in the provision of social housing for the lowest income range of housing programs in Brazil. Some previous studies have considered the benefits that mass customization could bring in the social housing context and indicated some paths for its implementation. However, most of these studies focus on only a few aspects of the provision process or do not refer to post-occupancy as part of the process and, thus, start from the premise that differentiation of the product must be for the initial unit. In contrast, this study argues that it would be more feasible and would bring more and longer-lasting benefits to the stakeholders involved if mass customization were applied with differentiation of the units happening post-occupancy.

Author Contributions: L.F.D.V. collected and analyzed the data and drafted the paper. B.K. provided guidance, editing, and reviewing for the paper. Both authors have read and agreed to the published version of the manuscript.

Funding: This research received no external funding.

Conflicts of Interest: The authors declare no conflict of interest.

\section{References}

1. Da Silveira, G.; Borenstein, D.; Fogliatto, F.S. Mass customization: Literature review and research directions. Int. J. Prod. Econ. 2001, 72, 1-13. [CrossRef]

2. Pine, B.J. Mass Customization: The New Frontier in Business Competition; Harvard Business School Press: Boston, MA, USA, 1993; ISBN 0875843727.

3. Tseng, M.M.; Jiao, J. Mass Customization. In Handbook of Industrial Engineering; Salvendy, G., Ed.; Wiley: Hoboken, NJ, USA, 2007; pp. 684-709. ISBN 9780470172339.

4. Rocha, C.; Formoso, C.; Tzortzopoulos, P. Adopting Product Modularity in House Building to Support Mass Customisation. Sustainability 2015, 7, 4919-4937. [CrossRef]

5. Kolarevic, B. Metadesigning Customizable Houses. In Mass Customization and Design Democratization; Kolarevic, B., Duarte, J.P., Eds.; Routledge: Abingdon-on-Thames, UK, 2019; ISBN 978-0-8153-6061-2.

6. Barlow, J.; Childerhouse, P.; Gann, D.; Hong-Minh, S.; Naim, M.; Ozaki, R. Choice and delivery in housebuilding: Lessons from Japan for UK housebuilders. Build. Res. Inf. 2003, 31, 134-145. [CrossRef]

7. Khalili-Araghi, S.; Kolarevic, B. Development of a framework for dimensional customization system: A novel method for customer participation. J. Build. Eng. 2016, 5, 231-238.

8. Lo, T.T.; Schnabel, M.A.; Gao, Y. ModRule: A User-Centric Mass Housing Design Platform. In Computer-Aided Architectural Design Futures. The Next City-New Technologies and the Future of the Built Environment; Celani, G., Sperling, D.M., Franco, J.M.S., Eds.; Springer: Berlin/Heidelberg, Germany, 2015; pp. 236-254. 
9. Duarte, J.P. Customizing Mass Housing: A Discursive Grammar for Siza's Malagueira Houses. Ph.D. Thesis, Massachusetts Institute of Technology, Cambridge, MA, USA, 2001.

10. Benros, D.; Duarte, J.P. An integrated system for providing mass customized housing. Autom. Constr. 2009, 18, 310-320. [CrossRef]

11. Noguchi, M.; Hernandez-Velasco, C.R. A “Mass Custom Design” Approach to Upgrading Conventional Housing Development in Mexico. Habitat Int. 2005, 29, 325-336. [CrossRef]

12. Tillmann, P.A. Diretrizes para a Adoção da Customização em Massa na Construção Habitacional para Baixa Renda; Universidade Federal do Rio Grande do Sul: Porto Alegre, Brazil, 2008.

13. Taube, J. Reflexões Sobre a Customização em Massa no Processo de Provisão de Habitações de Interesse Social: Estudo de caso na COHAB de Londrina-PR; Universidade Estadual de Londrina: Londrina, Brazil, 2015.

14. Taube, J.; Hirota, E.H. Customização em massa no processo de provisão de Habitações de Interesse Social: Um estudo de caso. Ambient. Construído 2017, 17, 253-268. [CrossRef]

15. Azuma, M.H. Customização em Massa de Projeto de Habitação de Interesse Social por Meio de Modelos Físicos Paramétricos; Universidade de São Paulo: São Carlos, Brazil, 2016.

16. Ministério do Desenvolvimento Regional. Sistema de Gerenciamento da Habitação. 2019. Available online: http://sishab.cidades.gov.br/ (accessed on 16 February 2020).

17. Groat, L.N.; Wang, D. Architectural Research Methods, 2nd ed.; John Wiley \& Sons: Hoboken, NJ, USA, 2013.

18. Brandão, D.Q. Disposições técnicas e diretrizes para projeto de habitações sociais evolutivas. Ambient. Construído 2011, 11, 73-96. [CrossRef]

19. Friedman, A. The Adaptable House: Designing Homes for Change; McGraw-Hill: New York, NY, USA, 2002; ISBN 0071377468.

20. Schneider, T.; Till, J. Flexible Housing; Architectural Press: Oxford, UK, 2007; ISBN 9780750682022.

21. NAURB-UFPel. Available online: https://wp.ufpel.edu.br/naurb/ (accessed on 11 August 2019).

22. Ministério da Cidadania. Cadastro Único. 2015. Available online: http://mds.gov.br/assuntos/cadastrounico/o-que-e-e-para-que-serve (accessed on 13 January 2020).

23. Rufino, M.B.C. Um olhar sobre a produção do PMCMV a partir de eixos analíticos. In Minha Casa e a Cidade? Avaliação do Programa Minha Casa Minha Vida em Seis Estados Brasileiros; Amore, C.S., Shimbo, L.Z., Rufino, M.B.C., Eds.; Letra Capital: Rio de Janeiro, Brazil, 2015; pp. 51-70. ISBN 9788577853779.

24. Ribeiro, C.; Kruger, N.; Oliveira, T. A Cidade e a Moradia: O caso de Pelotas. PIXO Rev. Arquitetura Cid. Contemp. 2017, 1. [CrossRef]

25. Palermo, C. Avaliação da qualidade no projeto de HIS: Uma parceria com a Cohab/SC. In Qualidade Ambiental na Habitação: Avaliação Pós-Ocupação; Villa, S.B., Ornstein, S., Eds.; Oficina de Textos: São Paulo, Brazil, 2013.

26. Ministério das Cidades Portaria No 660; Ministério das Cidades: Brasilia, Brazil, 2018.

27. Cardoso, A.L.; Mello, I.D.Q.; Jaenisch, S.T. A Implementação do Programa Minha Casa Minha Vida na Região Metropolitana do Rio de Janeiro: Agentes, Processos e Contradições. In Minha Casa e a Cidade? Avaliação do Programa Minha Casa Minha Vida em Seis Estados Brasileiros; Amore, C.S., Shimbo, L.Z., Rufino, M.B.C., Eds.; Letra Capital: Rio de Janeiro, Brazil, 2015.

28. Ministério das Cidades Portaria No 595; Ministério das Cidades: Brasilia, Brazil, 2013.

29. Ministério das Cidades Portaria No 21; Ministério das Cidades: Brasilia, Brazil, 2014.

30. Bonatto, F.S.; Miron, L.I.G.; Formoso, C.T. Avaliação de empreendimentos habitacionais de interesse social com base na hierarquia de valor percebido pelo usuário. Ambient. Construído 2011, 11, 67-83. [CrossRef]

31. Digiacomo, M.C. Estratégias de Projeto para a Habilitação Social Flexível. Master's Thesis, Universidade Federal de Santa Catarina, Florianópolis, Brazil, 2004.

32. de Jorge, L.O.; Medvedovsky, N.S.; Santos, S.; Junges, P.; da Silva, F.N. The spontaneous transformation of Anglo social housing complex in Pelotas/RS: Reflections about the urgency of the concept of Adaptable Social Housing. Cad. Proarq 2017, 122-153. Available online: https://cadernos.proarq.fau.ufrj.br/public/docs/ Proarq29\%20ART\%2007.pdf (accessed on 26 August 2019).

33. Marroquim, F.M.G.; Barbirato, G.M. Flexibilidade Espacial em Projetos de Habitações de Interesse Social. In Colóquio de Pesquisas em Habitação; EAUFMG: Belo Horizonte, Brazil, 2007.

34. Larcher, J.V.M. Diretrizes Visando a Melhoria de Projetos e Soluções Construtivas na Expansão de Habitações de Interesse Social. Master's Thesis, Universidade Federal do Paraná, Curitiba, Brazil, 2005.

35. Estevão, M.; Medvedovski, N.S. Entrevista com Mariana Estevão: A Prática da Arquitetura e Urbanismo com a Promoção à Saúde da População Brasileira. Expressa Extensão 2017, 22, 9-12. 
36. Lei $N_{0}$ 11.888; Casa Civil: Brasília, Brazil, 2008.

37. Sdino, L.; Castagnino, P. Housing Affordability Index: Real Estate Market and Housing Situations. In New Metropolitan Perspetctives: The Integrated Approach of Urban Sustainable Development; Bevilacqua, C., Calabrò, F., Della Spina, L., Eds.; Trans Tech Publications: Stafa, Switzerland, 2014; pp. 527-535.

38. Caixa Habitação Urbana-Minha Casa Minha Vida. 2019. Available online: http://www.caixa.gov.br/voce/ habitacao/minha-casa-minha-vida/urbana/Paginas/default.aspx (accessed on 16 May 2019).

39. Smith, R.E. Prefab Architecture: A Guide to Modular Design and Construction; John Wiley \& Sons: Hoboken, NJ, USA, 2010; ISBN 9780470275610.

40. Franke, N.; Schreier, M.; Kaiser, U. The "I Designed It Myself"; Effect in Mass Customization. Manag. Sci. 2010, 56, 125-140.

41. Kolarevic, B. From Mass Customisation to Design “Democratisation". Archit. Des. 2015, 85, 48-53. [CrossRef]

42. Merisio, B.G. Modificação da Habitação: Uma Avaliação Pós-Ocupação no Conjunto Habitacional de Interesse Social Ewerton Montenegro Guimarães em Vila Velha/Es; Universidade Vila Velha: Vila Velha, Brazil, 2016.

Publisher's Note: MDPI stays neutral with regard to jurisdictional claims in published maps and institutional affiliations.

(C) 2020 by the authors. Licensee MDPI, Basel, Switzerland. This article is an open access article distributed under the terms and conditions of the Creative Commons Attribution (CC BY) license (http://creativecommons.org/licenses/by/4.0/). 